\title{
Mandela, Human Rights and the Making of South Africa's Transformative Constitution
}

\section{TIMOTHY GIBBS*}

\author{
(University College London)
}

\begin{abstract}
Since 1994, numerous books have been written about South Africa's leadership of the human rights revolution. Such narratives lie at the heart of Nelson Mandela's Long Walk to Freedom and George Bizos' Odyssey to Freedom: a Memoir by the World Renowned Human Rights Advocate, Friend and Lawyer to Nelson Mandela. More recently, historians have taken a clearer-eyed view of the ANC's late conversion to the language of rights. They have mainly looked at how the ANC, an organisation rhetorically committed to revolution and suspicious of 'bourgeois rights', made an abrupt about turn and adopted human rights discourses in the late 1980s. This article takes a different course, opening up debates about the different meanings that rival groups of anti-apartheid lawyers attributed to the notion of human rights. At the start of the 1980s there was little common ground between the mainly liberal, mainly white, Lawyers for Human Rights, the Black Lawyer's Association demands for 'rights and recognition' and ANC exiles search for 'a liberated law' and 'popular justice'. I trace how these three broad strands of legal thinking converged during the 1980s around a common set of ideas: speaking of 'positive freedoms' that would undo the inequalities of the apartheid regime. By shepherding together these different groupings, the ANC leadership entered the constitutional negotiations that would usher in South Africa's democratic transition as the champion of human rights and 'transformative constitutionalism'. Nonetheless, sharp disagreements remained between rival groupings. This is one reason, I suggest, why 'Mandela's constitution' has recently become a lightning-rod for bitter debates about race and inequality and, more broadly, the meaning of human rights and transformation.
\end{abstract}

\section{Introduction}

On 13 February 1990, shortly after his release from prison, Nelson Mandela attended a

Welcome Home rally at Soccer City stadium in Soweto, packed with jubilant militant ANC supporters and a sprinkling of more circumspect international diplomats. Well aware of the gaze of the TV cameras, Nelson Mandela indicated that he wanted two white lawyers, George Bizos and Arthur Chaskalson, in the front row VIP seats on stage. Afterwards, Mandela briefly met Bizos and Chaskalson - who had both represented him since the 1960s - and told them to start drafting a constitution that was 'good not only for the ANC but for the country as well'. ${ }^{1}$ Four years later Nelson Mandela made Arthur Chaskalson, the most

* I would like to thank Colin Bundy for organising the workshop where I first tried out these arguments as well as Peter Brett, Juliette Genevaz and JSAS's anonymous reviewers. 
internationally renowned of South Africa's human rights lawyers, the first president of the new post-apartheid constitutional court.

Since 1994, numerous books and articles have been written about the ending of apartheid and South Africa's embrace - indeed its leadership - of the global human rights revolution. ${ }^{2}$ These arguments are mostly made in a major key, with Nelson Mandela often playing a leading part. Such narratives lie at the heart of Mandela's Long Walk to Freedom, as well as accounts such as George Bizos' Odyssey to Freedom: a memoir by the world renowned human rights advocate, friend and lawyer to Nelson Mandela. Another strand of writing celebrates the 'cascading' of (Western) Human Rights across the world, as the ANC leadership journeyed to constitutional workshops in the seminar rooms of Columbia University and Oxford in the late 1980s. ${ }^{3}$ The result, argue many, was post-apartheid South Africa's much lauded constitution: the first that (arguably) successfully embedded second generation socio-economic rights into the workings of the law courts. ${ }^{4}$ This argument about the emergence of constitutionalism in South Africa can also be told in a minor key. A few years ago when globalisation seemed triumphant, legal sociologists such as Yves Dezalay

Watching the Social and Economic Rights Institution (SERI) at work firsthand made think about these issues - many thanks, particularly to Julian Brown and Stuart Wilson.

${ }^{1}$ Constitutional Court Oral History Project, interview with George Bizos, 25 January 2012, p.5, available at

http://www.historicalpapers.wits.ac.za/?inventory/U/collections\&c=AG3368/R/9114, retrieved 20 June 2018.

${ }^{2}$ C. Sunstein, 'Social and Economic Rights? Lessons from South Africa', Constituional Forum, 11, 4 (2000/2001), pp.123-45; M. Tushnet, Weak Courts, Strong Rights: Judicial Review and Social Welfare Rights in Comparative Constitutional Law (Princeton, 2008).

${ }^{3}$ E. Borgwacht, A New Deal for the World: America's Vision for Human Rights (Cambridge Mass., 2007); D.M. Davis, 'Constitutional Borrowing: The Influence of Legal Culture and Local History in the Reconstitution of Comparative Influence', South African Legal Review, 1, 2 (2003), pp.181-95; H. Klug, Constituting Democracy: Law, Globalism and South Africa's Political Reconstruction (Cambridge, 2000).

${ }^{4}$ C. Sunstein, Designing Democracy: What Constitutions Do (Oxford, 2001), pp.221-38; T. Roux summarises: The Politics of Principle: The First South African Constitutional Court (Cambridge, 2013), pp.15-71, 262-303. 
and Bryant Garth argued that the global human rights revolution essentially embedded Western neo-liberal hegemony. ${ }^{5}$ More recently, as liberal internationalism has crumbled, so too the notion of human rights has lost its efficacy. ${ }^{6}$ This is the context in which South Africa today sees much loose talk about 'Mandela's constitution' and the 'liberal judiciary' having constrained the opportunity for radical reforms.

As a result of these highly charged debates, a number of legal-sociologists and historians are reconsidering the context in which South African politicians and lawyers came to draft the post-apartheid constitution, and the broader ideas that influenced them. ${ }^{7}$ This writing has the potential to open up politicised debates by investigating the heterodox ideas of rights thinking' that were circulating during the apartheid period. Thus far, much of this research has considered how the ANC (and the National Party too) came to speak the language of human rights in the 1970s and 1980s, in an era when the 'human rights revolution' was spreading across the world. ${ }^{8}$ In this article I take a different course - opening up discussions about the different meanings that rival groups of anti-apartheid lawyers attributed to the notion of human rights. The late Chief Justice Pius Langa famously described the post-

\footnotetext{
${ }^{5}$ Y. Dezalay and B. Garth, The Internationalisation of the Palace Wars: Lawyers, Economists and the Contest to Transform Latin American States (Chicago, 2002).

${ }^{6}$ T. Dunne and M. Hanson, 'Human Rights in International Relations', in M. Goodhardt (ed), Human Rights: Politics and Practice (Oxford, 2009), pp. 59-74.

${ }^{7}$ Dubow, Human Rights, pp.9-16. P. Brett 'The New Historiography of Human Rights' (unpublished paper, 2013), available at https://www.e-ir.info/2013/02/18/review-the-newhistoriography-of-human-rights/, retrieved on 18 June 2018.

${ }_{8}^{8}$ P. Brett, 'Explaining South Africa's Bill of Rights: an Interpretive Approach', Commonwealth and Comparative Politics, 52, 3 (2014), pp. 423-442; H. Brooks, 'Merging Radical and Liberal Traditions: The Constitution Committee and the Development of Democratic Thought in the African National Congress, 1986-1990', Journal of Southern African Studies, 44, 1 (2017), pp.164-87; S. Dubow, South Africa's Struggle for Human Rights (Athens OH, 2012); M. Gevisser, Thabo Mbeki: The Dream Deferred (Johannesburg, 2007), pp.526-37; O. Greene, 'The Embryonic State: Idealisms in an Armed Struggle', Radical History Review, 119 (2014), pp.146-60. H. Macmillan, Jack Simons (Johannesburg, 2016), pp.126-33; H. Macmillan, Oliver Tambo (Johannesburg, 2017), pp.112-31; Z.P. Jordan, Letters to My Comrades (Johannesburg, 2017), pp.51-76.
} 
apartheid constitution as 'a historic bridge between the past of a deeply divided [apartheid] society characterised by strife, conflict, untold suffering and injustice, and a future founded on the recognition of human rights'. ${ }^{9}$ In this article we see rival groups of lawyers within the anti-apartheid movement crossing this bridge, arguing with each other about how 'human rights' might contribute to the equally important South African idea of 'transformative constitutionalism'. These different visions of the transformations hoped for in a postapartheid society have been the source of enduring tension in South African human rights debates.

The opening sections of this article outline three rival strands of thinking about rights that emerged within anti-apartheid legal circles by the mid-1980s, at the time when the ANC was first putting together its constitutional committee. ${ }^{10}$ Section One outlines the most often told narrative: the struggle for human rights in South Africa led by a small coterie of (mainly white) lawyers whom, influenced by American ideas of democratisation and human rights, embraced the cause of liberal constitutionalism. Yet there were other important rival groupings. Section Two discusses the emergence of the Black Lawyers Association in a decade when a burgeoning generation of black South African lawyers were pressing for new forms of rights and recognition within the crumbling apartheid legal order. In particular, the BLA emphasised 'third generation human rights' that were being pioneered by AfricanAmerican lawyers in the United States and by institutions such as the Organisation of African Unity. Section Three reconsiders the remarkable intellectual journey made by exile lawyers

\footnotetext{
${ }^{9}$ This celebrated article judiciously synthesised South Africa's divergent human rights traditions: P. Langa, 'Transformative Constitutionalism', Stellenbosch Law Review, 3 (2006), pp.352.

${ }^{10}$ I primarily draw on interviews conducted by the Legal Resources Centre Oral History Project (hereafter LRCOHP), the Constitutional Court Oral History Project (hereafter CCOHP), and the interviews and biographical files of the Gerhart-Karis Collection (hereafter GKC), which are all found at the University of Witwatersrand Historical Papers.
} 
who would play significant roles within the ANC constitutional committee. In law faculties across the African continent in the 1960s and 1970s a loose grouping of socio-legal scholars had tasked themselves with of creating forms of 'popular justice' that would grapple with 'the dialectics of socialist struggle in post-independence Africa. ${ }^{11}$ But with the crumbling of African socialism in the 1980 s, many reinvented themselves as advocates of 'participative justice' and 'positive freedoms' that would 'undo the old [apartheid] regime's inequalities'. ${ }^{12}$

At the start of the 1980s it would have been difficult to see much common ground between the liberal Lawyers for Human Rights, the Black Lawyers Association's demands for 'rights and recognition' and exiles' search for 'popular justice'. But by 1990, the ANC had co-opted a broad tranche of anti-apartheid lawyers to its cause, not least with the publication of a Draft Bill of Rights that promised transformative, 'positive freedoms' to all citizens of South Africa. The fourth section of this paper sketches the course of these multi-stranded debates about human rights in the crucial years of the democratic transition. In one sense, it is indisputable that South Africa's established, well resourced, human rights fraternity crucially Arthur Chaskalson's Legal Resources Centre, which enjoyed the support of Nelson Mandela - played leading roles in the constitutional negotiations. ${ }^{13}$ At the same time, I hope to emphasise the importance of alternative groupings and ideas in shaping rights debates. For it was by building a wide alliance of anti-apartheid lawyers broadly in favour of 'positive freedoms' and a 'transformative constitutionalism' that the ANC prevailed in the constitutional negotiations.

${ }^{11}$ J. Oloka-Onyango, 'Review: Liberating the Law', Canadian Journal of African Studies 28, 2 (1994), p.362.

12 GKC, G. Gerhart interview, Albie Sachs, 9 September 1997.

${ }^{13}$ R. Spitz and M. Chaskalson, The Politics of Transition: A Hidden History of South Africa's Negotiated Settlement (Oxford, 2000). Also: H. Corder, 'South Africa's First Bill of Rights: Random Recollections of one of its Drafters', International Journal of Legal Information, 32, 2 (2004), pp.316-7. 


\section{Rival ideas - defending Human Rights}

It was only at the end of the 1970 s, at a moment when human rights rhetoric was enjoying renewed resurgence worldwide, that organisations such as Lawyers for Human Rights (established1979) and the Legal Resource Centre (1978/9) were first launched in South Africa. ${ }^{14}$ Yet in another sense, to paraphrase Kenneth Broun, it was the task of 'saving Nelson Mandela' and his co-accused at the Treason trial (1958-61) and Rivonia trial (1963-4) which first crystallised the networks of South African human rights lawyers, which would prove so important across the apartheid era. ${ }^{15}$

The Rivonia trial, in particular, made Nelson Mandela and his legal team icons of the emerging global human rights movement, which at that time was broadly campaigning for colonial freedom. Harvard legal scholars monitored the trial; UN institutions denounced the verdict. Mandela's resounding final statement convicted apartheid in the court of world opinion. The UK-based International Defence and Aid Fund, which funded the defence team, received donations from British law lords. More broadly, the legal networks established during the Treason and Rivonia trials endured across the apartheid era. The junior advocates (i.e. barristers) involved in Mandela's defence teams - particularly George Bizos (b.1927), Arthur Chaskalson, (1931-2012) and Sydney Kentridge (b.1922) - would go on to do many of the landmark political trials of the apartheid era. The iconography of the political trials was also an emotive political symbol. ${ }^{16}$ The formation of Southern Africa: The Imprisoned Society (established 1973) and the Release Mandela Campaign (1980) was so powerful

${ }^{14}$ S. Moyn, The Last Utopia: Human Rights in History (Cambridge Mass., 2010). S. Moyn (ed), The Breakthrough: Human Rights in the 1970s (Philadelphia, 2014).

${ }^{15}$ K. Broun, Saving Nelson Mandela: The Rivonia Trial and the Fate of South Africa (New York, 2012).

${ }^{16}$ Likewise, Joel Joffe (1932-2017), another of the Rivonia defence lawyers, later played a key role in establishing the London-based International Defence and Aid Fund (IDAF). 
internationally because it portrayed the jailed ANC leader not so much as a freedom fighter/terrorist as a prisoner of conscience. ${ }^{17}$

These early human rights networks were especially rooted in the Anglo-sphere - for London's centrality in the decolonisation of the British Empire (ironically) provided the dense networks that made the city one of the hubs of the global anti-apartheid movement. Thus the London-based International Defence and Aid Fund (IDAF) became the main vehicle for funding defence lawyers during political trials. IDAF raised more than $£ 50 \mathrm{M}$ as successive generations of South African political activists went on trial in the 1960s, 1970s and1980s. ${ }^{18}$ Canon Collins (1905-1982), the dean of St Pauls Cathedral, London, who established IDAF in 1956, epitomises a number of strands of human rights thinking that were closely linked to the radical ideas of the mid-twentiethcentury. As well as running IDAF, Collins was a founder member of War on Want and the Campaign for Nuclear Disarmament. Having entered public life espousing ideas of 'Christian Humanitarianism' in the 1940s, by the time of his death in the 1980s Collins was in the forefront of some of the leading new social movements that characterised the emergence of what Hakan Thorn calls a 'global civil society'. ${ }^{19}$

In 1979, Arthur Chaskalson left a lucrative career at the Johannesburg bar to establish the Legal Resources Centre (LRC). This public interest litigation unit would win global renown

\footnotetext{
${ }^{17}$ CCOHP interview, Bizos. LRCOHP, George Bizos interview, 4 December 2007; Bizos, Odyssey to Freedom, pp. 175-90. Dubow, Human Rights, pp.75-7. G. Klein, 'The British AntiApartheid Movement and Political Prisoner Campaigns, 1973-1980', Journal of Southern African Studies, 35, 2 (2009), pp. 455-470.

18 'Obituary: Phyllis Altman', Guardian, 25 September 1999.

${ }^{19} \mathrm{H}$. Thorn, Anti-Apartheid and the Emergence of a Global Civil Society (Basingstoke, 2006). Dubow, Human Rights, p.78.
} 
in the 1980s for taking up a series of 'civil rights' type cases, which challenged apartheid laws that expanded the field of human rights and freedoms in South Africa.

Here, the LRC drew on new strategies and fundraising networks associated with the US civil rights movement. The husband and wife team of Sydney and Felicia Kentridge (1930-2015) played a pivotal role in this shift. South African born and Oxford educated, Sydney Kentridge had been the preeminent liberal human rights lawyer of his generation, making his name as the leading defence counsel in many of the political trials of the 1960s and 1970s. In 1978 he left South Africa for Britain where he established an equally rewarding career as a Queen's Council at the London bar. ${ }^{20}$ Nonetheless, the Kentridges continued to play a prominent behind-the-scenes role, putting together the funding networks that resourced the LRC's work. Rather than focusing on South African liberal philanthropists, they concentrated their efforts on US donor networks, winning large donations from Carnegie, Ford and Rockefeller, the patrons of the US civil rights movement. ${ }^{21}$ Thus a new set of US-focused human/civil rights ideas, and their associated donors and institutions, increasingly overlaid the older AngloSouth African networks.

Importantly, the LRC emerged at a time when the global human rights revolution was resonating within the South African legal fraternity. During the decades of high apartheid, 'the bar [councils] of Cape Town, Johannesburg \& Durban would make occasional statements supporting human rights, but the rest of the legal profession remained silent',

\footnotetext{
${ }^{20}$ Detractors called him 'a legal fat-cat': 'High Fees put Legal QCs in the Dock', Independent, 18 June 1998.

${ }^{21}$ LRCOHP interviews: Geoff Budlender, 14 December 2007; Arthur Chaskalson, 4 December 2007; Sydney Kentridge, 15 February 2006. The Oppenheimer Trust, a selfproclaimed supporter of liberal reform, was the LRC's only significant South African funder.
} 
remembered George Bizos..22 This changed in 1979, when Professor J. D. van der Vyer, a law professor who had been dismissed from the University of Potchefstroom for the liberal tenor of his academic arguments, organised South Africa's first international conference on human rights. A follow-up conference led to the establishment of Lawyers for Human Rights, whose first 400 members were primarily drawn from the legal centres of Cape Town, Durban and Johannesburg. ${ }^{23}$ Tellingly, the first co-chairs of LHR were leading figures in the South African legal world. Jules Browde (1919-2016) was chair of the Johannesburg Bar Council. Johann Kriegler (b.1932), who served as an acting-judge during the final years of apartheid, also sat on the boards of the LRC of Harry Oppenheimer's Urban Foundation, and was later appointed to the post-apartheid constitutional court. ${ }^{24}$

Prof. John Dugard's Centre for Applied Legal Studies (CALS), established in 1978 at the University of Witwatersrand and specialising in labour law, was another important feature in the South Africa human rights landscape, nurturing a younger generation of legal activists. In the early 1970s, many radicals in the National Union of South African Students had been electrified by 'Natal Fever': the Durban Strike wave that seemed to promise a new phase of dissidence against apartheid. Some were law studentsor retrained as attorneys, specialising in the burgeoning field of labour law, which grew as the black trade union movement increased from 17,000 members in 1979 to 1.2 million by 1990 . This course of action was epitomised by the prominent law firm established by Nicholas 'Fink' Haysom (an ex-president of the

\footnotetext{
22 Bizos, Odyssey to Freedom, p. 429.

${ }^{23}$ CCOHP interview, Johann Kriegler, 24 November 2011. Bizos, Odyssey to Freedom, p.431. Dubow, Human Rights, pp.84-6.

${ }^{24}$ Bizos, Odyssey to Freedom, pp.429-31.
} 
National Union of South African Students), Halton Cheadle and Clive Thompson (both extrade unionists) in $1978 .{ }^{25}$

In one sense, the public interest cases pioneered by these law firms broadened the scope of human rights activism to encompass 'second generation' socio-economic rights. The partners at Haysom, Cheadle and Thompson won path-breaking court cases that reshaped South African labour law. ${ }^{26}$ CALS established a gender unit, run by Cathi Albertyn, a veteran of NUSAS politics, which worked to 'mainstream gender' into rights debates. ${ }^{27}$ The LRC took on pioneering land rights case. In particular, the 'land lobby' that emerged from this strand of legal activism would develop radical ideas about land restitution and the transformation of property rights. ${ }^{28}$ At the same time, elements of the South African human rights fraternity acquired a harder, sometimes narrower, radical edge. Particularly in Johannesburg, there was a fiercely competitive group of young white lawyers, who were old friends from the closeknit world of radical student politics on the English speaking university campuses. They were known as 'the NUSAS boys'. ${ }^{29}$

${ }^{25}$ LRCOHP interviews: Dennis Davis, 5 September 2008; John Dugard, 18 November 2008; Peter Harris, 6 December 2007.

${ }^{26}$ R. Abel, Politics by Other Means: Law in the Struggle Against Apartheid, (London, 1995), pp.125-72.

${ }^{27}$ LRCOHP interview, Catherine Albertyn, 4 August 2008. S. Hassim, Women's Organisations and Democracy in South Africa: Contesting Authority (Madison, 2006), pp.129-64.

${ }^{28}$ LRCOHP interview, Aninka Claassens, 17 August 2008. A. Claassens, 'Compensation for Expropriation: The Political and Economic Parameters' (Community Law Project Working Paper, University of the Western Cape, 1993), available from https://dullahomarinstitute.org.za/about-us/our-historical-publications, accessed 18 June 2018. Spitz and Chaskalson, The Politics of Transition, p.316.

29 'The [LRC] Johannesburg office was a tough place... for people who didn't have a NUSAS background... for those who weren't part of the team - LRCOHP interview, Geoff Budlender, 14 December 2007. Also: LRCOHP interview, Mohammed Navsa, 4 December 2008. 
In the mid-1980s, as the apartheid regime crumbled, South Africa's human rights legal fraternity started thinking about constitutionalism in the post-apartheid legal order. Once again, the American connection was crucial. Jack Greenberg, a former director-counsel to the NAACP and one of the founding members of Human Rights Watch in 1978, started teaching seminars on human rights and constitutionalism when at Harvard and Columbia in the 1980s. During visits to South Africa on human rights missions, he made close connections to the penumbra of South African lawyers closely associated with the CALS, the LRC, and LHR. George Bizos and Arthur Chaskalson, in particular, became very close to him when they took sabbaticals in New York to teach human rights and constitutional law seminars at Columbia University. ${ }^{30}$ The Ford Foundation, which was well known for supporting the cause of 'human rights and democratisation' in the Eastern Bloc and the Global South, also played an important role as one of the major sponsors of human rights work in South Africa. ${ }^{31}$

As Nelson Mandela looked to turn the ANC towards a negotiated settlement in the 1980s, these connections between South Africa's liberal lawyers and the Western democratisation and human rights movement became increasingly important. Here, the personal was political. Mandela's relationship to George Bizos, Arthur Chaskalson and Sydney Kentridge stemmed back to the Rivonia Trial. More importantly, Bizos acted as a personal counsel to Mandela and his family during the time he was jailed on Robben Island. In consequence, Bizos became a legal-statesman of sorts in the late 1980s, conveying messages between Mandela and Oliver Tambo in Lusaka, as the exiles and Robben Island leadership sought to

${ }^{30}$ CCOHP interview, Geoff Budlender, 6 January 2012. LRCOHP interview, Jack Greenberg, 8 November 2007. Bizos, Odyssey to Freedom, pp.471-3. Admittedly, Greenberg invited ANC exiles to Columbia; but reading between the lines there was often a sense of unease: cf. T. Hughes, 'Interview with Albie Sachs' Reality (July 1990), p.93; GKC, Tom Karis interview, Zingilize Jobodwana, 12 May 1989; GKC, Gail Gerhart interview, Penuell Maduna, Spring 1987.

${ }^{31}$ Dezalay and Garth, Palace Wars, pp.69, 127-9, 137-8, 147-9. Also: T. Shaw, 'Tribute to Jack Greenberg', Columbia Law Review, 117, 5 (2017), pp.1057-67. 
co-ordinate their positions. ${ }^{32}$ Through these networks, Nelson Mandela was able to project himself from Robben Island (and later Pollsmoor Prison) as a prisoner of conscience and an advocate of democracy and human rights.

\section{Rival ideas - rights and recognition}

Of course the liberal human rights lawyers associated with the LRC, LHR and CALS were not the only players; Nelson Mandela was also well connected to important groupings of black lawyers who came to the fore in the late 1970s, making renewed demands for rights and recognition. Godfrey Pitje, a former ANC Youth Leaguer who had served his articles (i.e. legal apprenticeship) with the Mandela and Tambo law partnership in the 1950s, founded the Black Lawyers Association (BLA) in 1977. The emphasis on black empowerment made by the BLA would eventually ultimately become synonymous with another important strand of 'transformative constitutionalism'.

Godfrey Pitje's chairmanship of the BLA points towards the affinities between the BLA's demands for rights and recognition and the legal struggles of the mid-twentieth century. Looking back on the 1950s, Nelson Mandela later described in Long Walk to Freedom the importance of legal representation in a racially segregated society, in which ordinary Africans were routinely harassed and humiliated by apartheid laws. He himself had had his legal credentials called into question by an apartheid judge (a common experience for black lawyers). He had also seen many of his African clients have their business license applications rejected by apartheid authorities for the sole reason that they were black. Reflecting on these experiences, he later wrote:

${ }^{32}$ Bizos, Odyssey to Freedom, pp.418-21. 
I quickly realised what [the] Mandela and Tambo [law firm] meant... It was a place where they could come and find a sympathetic ear and a competent ally, a place where they would not be either turned away or cheated, a place where they might actually feel proud to be represented by men of their own skin colour [my italics]. ${ }^{33}$

These ideas of Black self-advancement had been simmering since that time and were given momentum by black consciousness ideas. The contextual change was the transformation of South African legal profession: in 1960 just one dozen $(0.004 \%)$ of the 3,000 practicing attorneys in South Africa were African; by 1985, black lawyers made up 10 per centof the 6,500 attorneys in the legal profession. ${ }^{34}$ Indeed, the BLA's first case backed the application of the Pan African Congress stalwart, Dikgang Moseneke to join the Pretoria society of attorneys. Subsequently, Moseneke set up a firm with Willie Seriti and George Maluleke in downtown Pretoria, in defiance of apartheid laws. 'We needed to reinstate our own selfworth by putting up a respectable and competent professional practice in the eyes of our clients and of our white counterparts. We had stereotypes to slay and prejudices to vanquish,' recalled Moseneke in his memoirs, My Own Liberator. ${ }^{35}$

The BLA drew on a variety of ideological sources. It was formed at a time when the Organisation of African Unity was drafting the African Charter on Peoples' and Human Rights, which spoke of 'third generation' identity rights and well as 'second generation'

\footnotetext{
${ }^{33}$ Mandela

${ }^{34}$ L. Pruitt 'No Black Names on the Letterhead? Efficient Discrimination and the South African Legal Profession', Michigan Journal of International Law, 23, 3 (2002), p.562. 35 Moseneke, My Own Liberator, KL 2851-2852, 2865-2869. 'History of the Black Lawyers' Association' (n.d.), available at http://www.bla.org.za/asp/content_sub.asp?id=4andsid=3, accessed 16 June 2017.
} 
socio-economic rights. ${ }^{36}$ Most immediately, the Black Consciousness Movement, which was at the height of its influence in South Africa, provided a rallying ground for a variety of political standpoints. Godfrey Pitje, the first director of the BLA, hailed from the Africanist wing of the ANC. Dikgang Moseneke, the BLA's second director, had been jailed on Robben Island in his youth for his membership of the Pan African Congress. Others were involved in the Black Consciousness inspired Azanian People's Organisation. The inaugural conference of the BLA in Johannesburg received messages of support from the new Black Consciousness organisations that emerged during the 1970s: from the Black Management Forum, the South African Black Social Workers Association, the National Council of Women, and the Black Theology Caucus. ${ }^{37}$

In particular, the BLA looked towards the US for sources of funding and ideas - for this was also the decade when ideas of 'affirmative action' were making their way into the US legal profession. ${ }^{38}$ In 1984 Geoffrey Pitje left his practice to become the director of the BLA's legal education centre, which organised trial advocacy training and clerkships for young black lawyers. Dikgang Moseneke also played a central role in fundraising efforts. Having initially been palmed-off with modest grants from major donors, Moseneke recalled gatecrashing the offices of the Ford Foundation and winning a personal meeting with Franklin A. Thomas, the organisation's first African-American president. Thus the Ford Foundation became the BLA's anchor sponsor during its formative years. Later, a Rockefeller funded grant allowed the BLA to bring over 'four African-American lawyers who were champions

${ }^{36}$ More broadly, this was the time when communitarian political philosophies, exemplified by thinkers such as Alastair MacIntyre and Michael Sandel, were challenging the liberal theories of equality espoused by John Rawls and Ronald Dworkin.

${ }^{37}$ Moseneke, My Own Liberator, KL 3397-3400.

${ }^{38}$ Ironically, Jack Greenberg came to epitomise 1980s debates about race and representation in the USA, when African-American students boycotted a course he taught at Harvard, protesting it should instead by taught by tenured black professors - cf. Shaw, 'Greenberg', pp.1063-4. 
of civil rights', including judges Julius Higginbottom and Thomas Henderson. 'The visit was remarkable', remembered Dikgang Moseneke. For in the mid-1980s 'the all-white male judiciary was [still] an annexe of [apartheid South Africa's] racialised and gendered social arrangements', ${ }^{39}$

The intellectual and political odyssey of post-apartheid South Africa's third chief justice, Sandile Ngcobo (b.1953), gives a flavour of the times. He graduated with a B.Proc (a Bachelor in Law) from the University of Zululand in 1975 and then was imprisoned for his involvement in Black Consciousness inspired campus protests. On release, he worked for short periods as a government lawyer, in private practice, and with the LRC in Durban, before winning a Fulbright Scholarship and then a Harvard Human Rights Scholarship which took him to a series of Ivy League universities. In America he clerked for Justice Higginbottom and also 'helped teach a seminar... [on] "Race Values and the American Legal Process" at the University of Pennsylvania, Harvard Law School and Stanford Law School'. He eventually returned to Durban, where he combined private practice with part-time lecturing at the University of Natal. He taught courses on race legislation and constitutional law, coordinated 'the Equal Opportunities Project of the Centre for Socio-Legal Studies', and authored papers on 'topics such as justice... housing segregation and gender equality.' ${ }^{40}$

Given this stellar trajectory, Sandile Ngcobo was quickly raised to the bench and then the constitutional court in post-apartheid South Africa. A colleague remarked that Ngcobo initially seemed marginalised in the constitutional court by 'the mutual interaction and consensus amongst a core of the stronger-voiced members... who all happened to be white...

\footnotetext{
${ }^{39}$ Moseneke, My Own Liberator, KL 3456-3457.

40 Justice Sandile Ngcobo biography (n.d.), available at http://www.constitutionalcourt.org.za/site/judges/justicesandilengcobo/index1.html, retrieved on 18 June 2018.
} 
[But] the sheer brilliance of his legal thinking and writing established very quickly that he could more than hold his own', ${ }^{41}$ Thus a black consciousness tradition of legal thinking, which focused on 'third generation' human rights and called for 'transformation' of society and the judicial system, became an important part of the South African legal field.

At the start of the 1980s, there were deep divisions in South Africa between the Black Lawyers Association and organisations such as the Legal Resources Centre and Lawyers for Human Rights. Dikgang Moseneke, for instance, described Lawyers for Human Rights as a liberal, white establishment organisation that made largely rhetorical denunciations of apartheid. ${ }^{42}$ There was also an element of professional jealousy here. Whilst donors such as the International Defence and Aid Fund (IDAF) provided some funding to a handful of black law firms that took on political cases, the majority of resources - (at least in the opinion of some black lawyers) - went to the white advocates leading the high profile trials. ${ }^{43}$ By the end of the decade, however, a much broader grouping of lawyers were affiliated to what might be broadly described as human rights organisations and legal initiatives.

Most important was the formation of the National Association of Democratic Lawyers (NADEL) in 1987. NADEL described itself as a 'Charterist' organisation, signed-up to the 1955 ANC Freedom Charter, which it argued provided the foundational ideas of fundamental rights and freedoms that should be extended to all citizens of all races a post-apartheid South

${ }^{41}$ CCOHP interview, Sachs, p.69. Also, CCOHP interviews: Edwin Cameron, 9 December 2011, p.34; Sibongile Dube, 19 December 2011, pp.6-8

${ }^{42}$ GKC, Gail Gerhart interviews, Dikgang Moseneke, 2 July 1980 and 26 February 1986. Also: CCOHP interview, Pius Langa, 1 December 2011; Bizos, Odyssey to Freedom, pp.33, 431-2; LRCOHP interview, Nicholas Haysom, 8 February 2008.

${ }^{43}$ Moseneke, My Own Liberator, KL3354-61. Zingilise Jobodwana complained that the vast legal fees swallowed by white defence lawyers during the Delmas Treason Trial threatened to bankrupt IDAF - cf. Karis interview. 
Africa. ${ }^{44}$ In Cape Town, it was Nelson Mandela's personal attorney, Dullah Omar, a lapsed member of the Non -European Unity Movement, who played a crucial role in bringing rival groupings together into the broad Charterist grouping. He would later serve as South Africa's first post-apartheid justice minister in the ANC government. ${ }^{45}$ Similarly, Pius Langa (19392013), the second chief justice of South Africa, also played a vital role in forging NADEL from the three most important groupings of black lawyers: the Transvaal-based Black Lawyers Association, the KwaZulu Natal based Democratic Lawyers Association, and the Cape-based Democratic Lawyers Organisation. ${ }^{46}$ Langa was steeped in Charterism. One younger brother was in exile with the ANC. Another was taking legal articles with Griffiths and Victoria Mxenge, whose Durban based law firm was at the centre of ANC/Charterist networks in the city. The connections between Durban's Charterist lawyers and the ANC underground were thick. A number of attorneys training with the Mxenges - including Ben Langa, Patrick Maqubela and Bulelani Ngcuka - were active in the ANC underground. Langa also had an important connection to Robben Island through his work with the Release Mandela Committee. Thus Charterist networks - which led back to Nelson Mandela and the traditions of the Freedom Charter - became increasingly important in the 1980s drew out.

However, NADEL's decision to embrace of the Freedom Charter came at a price. NADEL's first president, Dumisa Ntsebeza, a human rights lawyer who served on the executive of the Azanian Peoples' Organisation, feared an ANC takeover. He resigned his post and led a breakaway grouping that returned to the Black Lawyers Association in $1988 .{ }^{47}$ Three decades

\footnotetext{
${ }^{44}$ Dubow debunks the mythology of the Freedom Charter, whilst nonetheless noting that it has become an important symbol for constitutionalists in South Africa: Human Rights, pp.13$4,68-74$.

${ }^{45}$ GKC, Tom Karis interview, Dullah Omar, 29 November 1989.

46 'History of the BLA'

${ }^{47}$ GKC, Gail Gerhart interview, Dumisa Ntsebeza, 6 November 1987. 'History of the BLA'. Strikingly, a number of senior figures in the BLA - including Monjaku Gumbi, Dumisa
} 
later, the BLA and the NADEL remain separate organisations that espouse distinctive causes: NADEL often speaks of Charterist rights and freedoms; the BLA particularly promotes the racial transformation of the legal profession.

\section{Rival ideas - the search for popular justice}

Perhaps the most important of the legal groupings in the mid-1980s, given the crucial role they would play on the ANC constitutional committee, were the exiled lawyers scattered across southern Africa. In recent years there have been many assessments of the ANC constitutional committee, chaired successively by Jack Simons and then Zola Skweyiya. Many have emphasised the important role that leading exiles - particularly Oliver Tambo, Thabo Mbeki, and Pallo Jordan - played in giving the ANC's constitutional committee sufficient space to bring liberal arguments to the fore of these debates. ${ }^{48}$ This article covers different ground, instead focussing on how exile lawyers, whom in the 1960s and 1970s had spoken of 'liberating the law' to create a socialist post-colonial Africa, came to persuasively speak of 'positive freedoms' and 'human rights' by the end of the 1980s.

The intellectual journey made the veteran exile lawyer Albie Sachs in socialist Mozambique - who later played an influential role on the ANC constitutional committee - provides an important example of this metamorphosis of radical legal thinking. In 1977 Sachs arrived in Maputo, taking posts at the university and then the justice ministry, keen to play his part in a revolutionary Mozambique, believing that a whole new culture and society was being created in the wake of the collapse of colonial rule. Here he worked closely with Gina Honwana, his

Ntsebeza, and Willie Seriti - held senior positions in the Azanian Peoples' Organisation during this period: cf. Proud to be Black', Speak, February 1994, p.6.

48 Most accounts of these exile debates emphasise the dichotomy between liberal ideas of human rights and the socialist ideologues who dominated the armed wing of the ANC - cf. footnote eight. 
boss in the Mozambican Justice Department, and a rising generation of Mozambican law students and young judges on the project of 'implanting Popular Justice' into a liberated Mozambican society. For these were the decades when radical regimes across post-colonial Africa sought to reshape peasant societies along socialist lines; when professors in the faculties of law at Dar-es-Salaam, Harare and Maputo convened legal workshops and examined the doctoral dissertations of each others' students. ${ }^{49}$

Sachs and Honwana's relationship to the Mozambican revolutionary regime was seemingly ambivalent. On the on hand, they played a central role in establishing a new system of popular tribunals across Mozambique, which Sachs later described as 'one of the great achievements of the revolution'.$^{50}$ To this end, the rising generation of Mozambican law students and young judges were formed into 'small brigades' and sent into the countryside during the 1978 winter vacation ('the July activities') to establish pilot projects in popular justice. As a result these experiments, the Mozambican Justice Ministry's department for research formulated legislation that established 800 popular tribunals across the country.

We [even] brought out a magazine called Justiça Popular, totally different from any legal journal in the world. Lots of photographs of the community courts, some debates, some discussions, never long theoretical articles; but very much a body of knowledge, information, contestation of ideas, to be used by people in the justice sector, to enable them to see themselves and to take their work seriously. ${ }^{51}$

\footnotetext{
${ }^{49}$ LRCOHP interview, Sachs, pp38-9, 42. CCOHP interview, Sachs, p.6. On the political pilgrims who made Mozambique their home: M. Hall and T. Young, Confronting Leviathan: Mozambique since Independence (London, 1997), pp.62-3.

${ }^{50}$ A. Sachs and G. Honwana, Liberating the Law: Creating Popular Justice in Mozambique (London, 1990), p.6.

${ }^{51}$ LRCOHP interview, Sachs, pp.38-9, 42. Also: Sachs and Honwana, Liberating the Law, pp.9-11. A. Sachs 'Changing the Terms of Debate: A Visit to a Popular Tribunal in
} 
This 'project of popular justice... formed the spine of the [Mozambican] socialist order': a vision of socialist legality and popular sovereignty was very different from a 'bourgeois legality' and individual human rights. ${ }^{52}$

At the same time, Sachs retrospectively claimed that he had been nauseated by the more authoritarian aspects of the Mozambican revolution and its lack of regard for human rights. In 1983 Samora Machel announced the closure of the law faculty in a speech without any prior warning. That same year, Machel reintroduced public flogging - a colonial statute that had been discontinued, but never taken off the statute books - to quell black marketeers and 'economic saboteurs'. ${ }^{33}$ Looking back, Sachs and Honwana would paint themselves not such much as doctrinaire communists but more as fellow travellers of the radical left. Certainly, their hinterland was rooted in new left currents of legal thinking. Sachs was a lapsed member of the South African Communist Party who had spent much of the 1960s and 1970s teaching feminist and family law at Southampton University. Honwana was a scion of the 'small, emerging [African] middle-class, [which] linked up with the left-democratic' student

Mozambique', Journal of African Law, 28, 1/2 (1984), pp.99-106. B. Isaacman and A. Isaacman, 'A Socialist Legal System in the Making: Mozambique Before and After Independence', in R. Abel (ed.), The Politics of Informal Justice (London, 1981), pp.309-20. 52 J. Obarrio, The Spirit of the Laws in Mozambique (Chicago, 2014), p.46. Also: Sachs and Honwana, Liberating the Law, pp.15-6, 111-22. Nonetheless, by the mid-1980s Sachs was seeking to reconcile radical arguments for national liberation and popular sovereignty with 'bourgeois civil rights': 'Towards the Reconstruction of South Africa', Journal of Southern African Studies, 12, 1 (1985), pp.49-59.

53 Compare Sachs' wholehearted advocacy of the disastrous policy of land nationalisation with his half-hearted defence of public floggings: Sachs and Honwana, Liberating the Law, p.6. He later said: 'between 1977 and 1988 I went up with the Mozambican revolution [and] I came down with the Mozambican revolution' - LRCOHP interview, Sachs, p.38. His off the record comments are interesting too: KGC biographical files - letter to Gwen Carter, 16 June 1982; Tom Karis interview, 24 June 1983; 'Talk at the Phelps-Stokes Fund Dinner', 5 April 1989. 
movements whilst studying abroad in the years before Portugal's Carnation Revolution. ${ }^{54}$ Accordingly, their work on popular justice appealed to new left legal scholars researching participatory justice in the 1980s. They focused their attention on the lowest level of Mozambique's community courts, where ordinary villagers sought justice in their daily lives. There was also a significant strand of feminist thinking in these ideas of revolutionary, popular justice. For Mozambique's 1975 constitution spoke of 'eliminat[ing] the colonial and traditional structures of oppression and their corresponding mentalities'; specifically mentioning 'the liberation of women... [as] one of the essential tasks of the State'. ${ }^{55}$ Indeed, some of the work of the Mozambican Justice Ministry's department for research was funded by the Ford Foundation and the Norwegian government..$^{56}$

This intellectual heterodoxy meant that Sachs and Honwana were well placed to ride out the collapse of Communism. In the mid-1980s, well before the breaching of the Berlin Wall, African socialism was already collapsing in Mozambique. In the middle of a brutal civil war, the revolutionary government moved towards dirigisme. Even the community courts were 'more or less abolished in the end' ${ }^{57}$ Amidst these shifting sands of legal thinking, Sachs and Honwana struck an increasingly emollient tone when describing the purpose of their work. They downplayed the significance of socialist ideology and the national democratic revolution; instead emphasising how their legal project chimed with more fashionable ideas of community law, participatory development and women's legal rights..$^{58}$

\footnotetext{
${ }^{54}$ LRCOHP interview, Sachs, pp.35-7, 41-2, 45-6.

${ }^{55}$ G. Honwana, F. Dagnino and A. Sachs, 'Transforming the Foundations of Family Law in the Course of the Mozambican Revolution', Journal of Southern African Studies, 12, 1 (1985) pp.60-1.

${ }^{56}$ Sachs and Honwana, Liberating the Law, pp.22-5.

${ }^{57}$ LRCOHP interview, Sachs, p.45.

58 Sachs and Honwana, Liberating the Law, p.24, quoted by Hall and Young, Confronting Leviathan, p.217. Indeed, Gina Honwana continued her pursuit of community/popular justice after 1990 by leaving Mozambique for the UN system, as the Regional Director of the
} 
After surviving an assassination attempt perpetrated by apartheid security forces in $1988,{ }^{59}$ Sachs left Mozambique for London, where he sought to establish, with Ford Foundation, funding, a constitutional think-tank at the Institute for Commonwealth Studies. Here Sachs made close links to ANC exiles - particularly in the ANC Women's Section, who themselves were exploring questions of women's legal rights and community law. ${ }^{60}$ Despite the intellectual and political turbulence of the decade, Albie Sachs remained a romantic revolutionary, his ideas of a transformative constitutionalism drawing, somewhat quixotically, from his experience of 'popular justice' in revolutionary Mozambique. Indeed, when Sachs was later raised to the post-apartheid constitutional court and put in charge decorating South Africa's new constitutional court building, he commissioned rugs made by rural women's co-operatives: a self-conscious symbol of a lifelong commitment to participative justice. ${ }^{61}$

Importantly, the heterodox ideals of African socialism espoused by exiles such as Albie Sachs gained significant traction amongst some of the younger generations of law students who fled South Africa after 1976. Crucially, the ANC-in-exile bureaucracy organised studentships, allowing this rising generation to complete their legal degrees, mostly at the

United Nations Development Fund for Women (UNIFEM) in southern Africa and later the justice minister in the UN-led transitional government for East Timor.

${ }_{59}$ He was targeted - deliberately - on International Women's Day: J. Pauw, In the Heart of the Whore: The Story of Apartheid's Death Squads (Johannesburg, 1991), p.173.

${ }^{60}$ Sachs' closeness to ANC women's section was striking - cf. GKC Biographical files: 'An Interview with a Very Remarkable South African', Monitor, August 1990, p.88. GKC

interview, Sachs, 1989. For a more acerbic appraisal of the ANC women's section: Hassim, Women's Organisations, pp. 116-28.

${ }^{61}$ CCOHP interview, Yvonne Mokgoro, 24 November 2011, p.15. More broadly: D. Cornell and K. van Marle with A. Sachs, Albie Sachs and transformation in South Africa; from revolutionary activist to constitutional court judge (2014). 
University of Zambia, the University of Zimbabwe and the merged Universities of Botswana, Lesotho and Swaziland (UBLS). ${ }^{62}$ In this generation's political and ideological trajectories, we see how the ANC absorbed the ideas of the radical new left in the universities of southern Africa.

Take Brigitte Mabandla (b.1948), a chain-smoking student activist who finished her LLB at the University of Zambia, having fled into exile after being detained for organising student protests in support of revolutionary Mozambique. In apartheid South Africa, Mabandla had been prominent in the Black Consciousness student movement.In the 1980s, she found work in the ANC-in-exile's Department for Legal and Constitutional Affairs, where she developed an interest in women and children's rights, travelling to conferences organised in Prague and Vienna. ${ }^{63}$ She was brought into the ANC's constitutional committee - the only woman at the table - where she emerged as 'perhaps the most effective voice inside the ANC for gender equality'. ${ }^{64}$ She recalled that her ambition at that time was to serve as the inaugural head of a post-apartheid Human Rights Commission. Instead, after 1994 she ran a series of government ministries, eventually becoming South Africa's first female justice minister in 2004.

\footnotetext{
${ }^{62}$ In the early 1980s the ANC had 1500 students studying abroad: T. Lodge, 'State of Exile: The African National Congress of South Africa, 1976-86, Third World Quarterly, 9, 1 (1987), p.13. On studying law at the Universities of Lesotho and Zimbabwe: V. Pikoli and M. Weiner, My Second Initiation: The Memoir of Vusi Pikoli (Johannesburg, 2013), pp.86-90, 186-7. On the University of Zambia: H. Macmillan, The Lusaka Years: The ANC in Exile in Zambia (Johannesburg, 2013), pp.131-2.

${ }^{63}$ B. Mabandla, 'The Situation of Women in a Changing South Africa' (unpublished report, UN Centre for the Development and Advancement of Women, November 1991). B.

Mabandla, 'Increased Awareness by Women of Their Rights' (Conference Address, Prague, 1992). Both available from https://dullahomarinstitute.org.za/about-us/our-historicalpublications, accessed 18 June 2018. GKC biographical file, Brigitte Mabandla. P. O’Malley interview, Brigitte Mabandla, 13 January 1993.

${ }^{64}$ M. Gevisser, 'This Mensch is No Man', Mail and Guardian, 7 April 1995. Gerhart interview, Sachs, 1989.
} 
Another notable was Thuli Madonsela (b.1962), who took successive law degrees at the Universities of Swaziland (1987) and Witwatersrand (1990). Because of her Swazi-South Africa parentage, she oscillated between Soweto and Manzini during her formative years: the former the heart of the South African student movement; the latter containing the largest grouping of exiles. ${ }^{65}$ Madonsela then worked at the CALS Gender Unit with Kathy Albertyn during the constitutional negotiations, at a time when female lawyers and feminist activists across southern Africa were mobilising to make women's human rights an integral part of the constitutional order. ${ }^{66}$ After 1994, she rose through government as a legal adviser on gender machinery and transformation issues, becoming South Africa's public protector in 2009 thanks to nominations from the women's movement. ${ }^{67}$ This post would win her international fame as a human right's defender. Nonetheless, Madonsela would always remember her radical hinterland with great warmth. She named her eldest son Fidel (b.1989) - a homage to the Cuban revolution. ${ }^{68}$

The decisive clash between the Old Left and the New Left inside the ANC-in-exile came in the mid-1980s. Here, the young exiles, who went abroad in the aftermath of the 1976 Soweto student revolt, were deeply frustrated by the inertia, corruption and the repressiveness of the exile bureaucracy. Most immediately, there were deep tensions inside the exile camps inside southern Africa because of the extra-legal methods used by ANC counter-intelligence

${ }^{65}$ South African Institute of Race Relations, Race Relations Survey (Johannesburg, 1983), p.63.

${ }^{66}$ The vibrancy of these debates is seen in the many edited collections: e.g. J. Stewart and A. Armstrong (eds), Women and the Law in Southern Africa (Harare, 1987). S. Bazilli, Putting Women on the Agenda (Johannesburg, 1991). J.E. Stewart and W. Ncube with K.C. DenguZvobgo (eds), Standing at the Crossroads: WLSA and the Rights Dilemma (Harare, 1997).

${ }^{67}$ T. Gqubule, No Longer Whispering to Power: The Story of Thuli Madonsela (Johannesburg, 2017), pp.28, 1-62 passim. More broadly: Hassim, Women's Organisations, pp.212-33.

${ }^{68}$ Gqubule,Madonsela, pp.41-55. 
(Mbokodo) against suspected spies and traitors. More broadly, many of the younger generation were impatient with doctrinaire Communism. Jabulani 'Mzala' Nxumalo, a former law student who had fled into exile in the late 1970s, only lasted a short time at the World Marxist Review in Czechoslovakia because his restless intelligence disturbed more dogmatic senior comrades. Likewise, Zola Skweyiya (1942-2018), the head of the ANC's Department for Legal Affairs in the 1980s, had been deeply alienated by his time in East Germany, where he taken an LLM at the University of Leipzig.

The intellectual odyssey made by Jack Simons, the first chair of the ANC constitutional committee, sheds lights on these debates. A longstanding communist, Simons went into exile in 1965, taking up a teaching post at the University of Zambia. Although he had run seminars on scientific socialism for Kenneth Kuanda's cabinet, he soon came to despair of Kaunda's programme of 'African Humanism' and tacitly supported the student protests that followed a university theatre production of 'King Kazembe and the Portuguese'. In the late 1970s, Jack Simons took two periods of sabbatical to teach courses on history and political theory in the ANC camps in Angola, which had absorbed many of the 15,000 youngsters who had fled South Africa for exile. ${ }^{69}$ Simons was cherished in the Angola camps, remembered one of his best loved protégés, Charles Nqakula (b. 1942) - who, perhaps not un-coincidentally, was a lawyer by training ${ }^{70}-$ because he 'took delight in puncturing... dogmatism'. ${ }^{71}$ Simons' significant intellectual contribution whilst in exile included his his indictment of the colonial

${ }^{69}$ H. Macmillan, 'Obituary: Jack Simons' JSAS, 21, 4 (1995), p.690. H. Macmillan, 'The University of Zambia and the Liberation of Southern Africa, 1966-90', JSAS, 40, 5, (2014), pp.949-51.

${ }^{70}$ Nqakula had trained as an attorney with Hintsa Siwisa's Eastern Cape law practice - cf. C. Nqakula, The People's War: Reflections of an ANC Cadre (2017), p.14.

${ }^{71}$ C. Nqakula, 'Jack Simons: Teacher, Student of Life, Communist', African Communist, 142 (1995), available at

https://omalley.nelsonmandela.org/omalley/index.php/site/q/031v02424/04lv02730/051v0300 5/061v03006/07lv03105/081v03116.htm, retrieved on 18 June 2018. 
and apartheid legal system in in African Women: their legal status in South Africa (1968). Simons' young students - some of them South African exiles - saw in the book a broader condemnation of repressive legal apparatuses of all creeds and colours. ${ }^{72}$

In 1985, questions of revolutionary legality and political pluralism bubbled up at the ANC's consultative conference in Kabwe, Zambia. The youngsters in the hall demanded open ballots (rather than backroom deals) when they voted delegates onto the ANC's governing National Executive Council. Jack Simons gave a paper on Our Freedom Charter, arguing 'for formal equality of rights' - 'not just a factual or socialist equality' - 'for all persons regardless of race, colour or sex... [in] a united, non-racial and democratic South Africa' ${ }^{73}$ Albie Sachs also made a passionate speech from the podium, calling for a code of conduct that would check the 'intensive interrogations' of suspected informants. Sachs later recalled how one by one the delegates - 'especially the young people from Umkhonto weSizwe' - stood up to denounce the torture and abuses conducted by Mbokodo. 'I remember one young chap saying: "we are fighting for life; how can we be against life?" 74 Thus an alliance of "the young soldiers and the not-so-young lawyers' to some extent prevailed at the Kabwe conference. ${ }^{75}$

A number of historians have seen the mid-1980s as the moment when the ANC-in-exile and the Robben Islanders came to tentatively embrace the cause of human rights. One of the results of the Kabwe Conference was that Jack Simons was tasked to set up a committee that

\footnotetext{
72 Nqakula, 'Jack Simons'.

${ }^{73}$ Macmillan, Jack Simons, p.127.

${ }^{74}$ LRCOHP interview, Sachs p. 49. Also: Nqakula, People's War, pp.18-20; Dubow, Human Rights, pp.94-5, 141 fn147 \& 149.

${ }^{75}$ Nqakula, Peoples' War, p.19. Nonetheless, the MK obstructed the newly appointed officer of justice, Zola Skweyiya, and it took four internal inquiries to get to the bottom of the abuses: Dubow, Human Rights, p.94.
} 
would draft a constitution based on the ANC's legendary 1955 Freedom Charter. Hugh Macmillan goes so far as to argue that the ANC president, Oliver Tambo, a committed Christian and a social democrat, quietly told Jack Simons that a 'draft constitution should provide for a multi-party electoral system, a mixed economy and an entrenched bill of rights' ${ }^{76}$ Likewise, Nelson Mandela emphasised his commitment to the principles of democracy and human rights embodied in the Freedom Charter when meeting the international delegations that visited him in prison. ${ }^{77}$ Yet not all reformists saw the direction of the constitutional debates pointing in this direction. Many still believed that a reformed socialism could be forged, which would have "nothing to do with bureaucratic repression... and everything to do with humanism and democracy'. ${ }^{78}$ Even after the fall of the Berlin Wall, Jack Simons believed that 'Marxism-Leninism will survive the blunders and crimes committed in its name' ${ }^{79}$

\section{Transformative constitutionalism triumphant?}

In February 1990, three months after the fall of the Berlin Wall, Nelson Mandela was released from prison. At this time of political and ideological upheaval, as South Africa stood on the cusp of a historic democratic transition, the ANC constitutional committee rallied to a new standard. In November 1990 it published a substantial Working Document on a Bill of Rights that would extend 'positive', transformative freedoms to all citizens of South Africa. Crucially, this argument was made in a number of different registers. Exiles with a jaundiced

\footnotetext{
${ }^{76}$ Macmillan, Oliver Tambo, p.122.

${ }_{77}$ Mandela, Long Walk, pp.629, 642-4.

${ }^{78}$ Nqakula, 'Jack Simons'. Also: Brooks, 'Constitutional Committee'; Macmillan, Jack Simons, pp.130-33.

${ }^{79}$ Macmillan, Jack Simons, p.7, pp.134-41.
} 
view of Communism, such as Zola Skweyiya, wrote of rooting democracy in African soil. ${ }^{80}$ Others argued that the ANC was advocating an anti-fascist constitution (rather than 'a [narrowly] liberal constitution') that would 'undo the old [apartheid] regime's inequalities' ${ }^{81}$ Here, Albie Sachs played a particularly important role in emphasising 'affirmative action': arguing that 'a bill of rights... could be used to guarantee the very rights and freedoms so long denied to the [black] majority'. ${ }^{82}$ (In 1988 a meeting of student radicals at the University of the Western Cape warned that 'a bill of rights could simply be a tool... to subordinate the working classes'. ${ }^{83}$ Likewise, the ANC women's section argued for 'positive freedoms', pushing hard for the movement to either adopt a charter for women's rights or at least to embed gender equality within a wider bill of rights. ${ }^{84}$

One achievement of this bill of rights was to weld together the three rival strands of legal thinking - liberal demands for human rights, the BLA's demands for 'rights and recognition', and ANC exiles search for 'a liberated law' - which, in any case, were already converging in the late 1980s. The ANC Freedom Charter came to serve as a rallying point for many within the broad anti-apartheid movement, promising 'positive' transformative freedoms to all the people of a post-apartheid South Africa. ${ }^{85}$ Importantly too, ANC-aligned academics and activists established their own constitutional think-tank, the Community Law Centre at the University of the Western Cape in 1990. Funded, once again, by the Ford Foundation, the first director was Dullah Omar. ANC activists such as Brigitte Mabandla worked for and

${ }^{80}$ Z. Skweyiya, 'Democracy on the African Soil' (Constitutional Law Centre Occasional Paper, 1992), available from https://dullahomarinstitute.org.za/about-us/our-historicalpublications, accessed 18 June 2018.

${ }^{81}$ Gerhart interview, Sachs, 9 September 1997.

${ }^{82}$ Brooks, 'Constitutional Committee', p.174.

${ }^{83}$ Dubow, Human Rights, p.111.

${ }^{84}$ Yet note the struggles that feminists faced trying to integrate women's rights into ANC policy - cf. F. Ginwala, 'Women and the Elephant: The Need to Redress Gender Oppression', in S. Baziilli (ed.), Putting Women on the Agenda, pp.62-74.

${ }^{85} \mathrm{Cf}$. footnote 43 . 
published extensively with the think-tank. It also issued papers written by sympathetic interlocutors such as Arthur Chaskalson. Likewise, Amy Biehl, the American anti-apartheid activist was working with the think-tank on a Fulbright Scholarship, when she was tragically killed in Cape Town in 1993. ${ }^{86}$ Albie Sachs later boasted that the Community Law Centre was one of the 'engine rooms of the intellectual foundations that were being laid for the new constitution in South Africa' ${ }^{87}$ Its alumni include future justice ministers, constitutional court justices, and post-apartheid South Africa's first national public prosecutor/attorney general.

Yet old suspicions remained. In the same year that the ANC made its constitutional proposals, Albie Sachs released an accompanying book on Advancing Human Rights in South Africa (1990). His book became a lightning-rod for attacks against these ideas of 'positive freedoms'. Some book reviews argued that measures such as affirmative action essentially reintroduced apartheid-like notions of group rights through the back door. ${ }^{88}$ One reviewer suggested a better title would have been, 'Advancing ANC/SACP Control of South Africa' ${ }^{89}$ The influential coterie of South African liberal lawyers seem to have been sceptical too later bringing in their own experts in constitutional law to draft South Africa's bill of rights, rather than leaving such an important task to a maverick exile. ${ }^{90}$

${ }^{86}$ A list of publications is found at https://dullahomarinstitute.org.za/about-us/our-historicalpublications, accessed 18 June 2018.

87 Community Law Institute interview, Albie Sachs (n.d.), available from https://dullahomarinstitute.org.za/clc25-interviews, accessed on 18 June 2018.

${ }^{88}$ D. Leyshom [a lecturer in constitutional law at Rhodes University], 'Sachs: A Visionary with Resentments', Monitor (December 1990), pp.69-71. D. Caldwell, 'My Group Rights are Better than Yours', Frontline (December 1990), p.11. C. Keegan, 'Romancing the Revolution', Leadership (December 1990).

${ }^{89}$ J. Mitchell, ‘Another Title Would Serve Cause Better', Star, 5 August 1990. ${ }^{90}$ CCOHP interview, Davis pp.12, 19. Indeed, Sachs' visceral hostility to Western liberal theorists such as John Rawls bemused sympathetic interlocutors - cf. Gerhart interview, Sachs, 1989. 
Whilst Albie Sachs had been a central protagonist in the debates that won over the ANC to the idea of human rights, he would play peripheral role in the actual constitutional negotiations that started in December 1991. Instead, Nelson Mandela appointed Arthur Chaskalson as his chief legal adviser in the negotiations. George Bizos (Mandela's personal lawyer) and Fink Haysom (who later served as Mandela's presidential legal adviser) also played important roles behind the scenes. ${ }^{91}$ Thus the legal drafting of South Africa's constitution in the early 1990 s came to be dominated by a close-knit grouping that hailed from the worlds of the liberal, English speaking law faculties. ${ }^{92}$

Under the guiding hands of Mandela's hand-picked lawyers, the broad idea of 'transformative constitutionalism' became widely accepted by almost all parties in the constitutional negotiations. The ANC won the battle of ideas inasmuch as it was impossible to disagree with a common sense proposition: that a 'commitment ... to transform our society ... lies at the heart of the new constitutional order'. ${ }^{93}$ By the early 1990s, not even negotiators from the governing National Party could argue against that.

Yet significant disagreements remained. The views of the Democratic Party - which played a pivotal role in the negotiations, not only because it positioned itself as a liberal midpoint between the ANC and NP, but because it was full of sharp minded experts from the liberal

${ }^{91}$ CCOHP interview, Davis, pp.12-3. Haysom was also close to the ANC's chief negotiator, Cyril Ramaphosa, having won important cases for Ramaphosa's National Union of Mineworkers in the 1980s.

${ }^{92}$ A sense of this closed, clubby world comes across in best blow-by-blow account of the process of writing the constitution by Spitz and Chaskalson, The Politics of Transition. CCOHP interviews are also revealing.

${ }^{93}$ Langa, 'Transformative Constitutionalism', p.351. 
legal establishment - is instructive here. At the negotiations table, the Democratic Party came to support transformative constitutionalism, insofar as their bill of rights proposals endorsed 'differentiation designed to overcome disadvantage'. ${ }^{94}$ The DP's conceptions of socioeconomic rights derived from what might be broadly termed liberal ideas of equality - the theories of John Rawls and Ronald Dworkin, which had been discussed in the seminar rooms of Columbia and Oxford. Tellingly, the Democratic Party's initial proposals for a South Africa's bill of rights never overtly spoke of 'women's rights', ‘workers', or 'affirmative action'. 95

In particular, the question of property rights was acutely contentious in negotiations over both the interim and the final constitution, given that this issue symbolised the deep material inequalities in South Africa. Moseneke spoke for many in arguing that a 'property clause, in effect, sanitised historical dispossession and entrenched proprietary benefit and privilege of an unequal past' ${ }^{9}{ }^{96}$ The PAC and AZASO legal teams at the negotiations wanted minimal protection of established property rights and mooted expropriation without compensation. Similarly, radical voices in the ANC, such as Dullah Omar, feared 'entrenching the rights of [established] right-holders and the rightlessness of the rightless'.${ }^{97}$ Likewise, the radical land lobby argued that any constitutional clause guaranteeing property rights 'should not apply to measures aimed at bringing about land reform'. A Democratic Party parliamentarian later remembered (somewhat smugly) that 'the answer to emotion had to lie in reason', and how they smuggled a moderate compromise clause into the final text with the help of the ANC's

\footnotetext{
${ }^{94}$ A. Sachs, 'Lean and Clean: But the DP Dodges Difficult Rights', Weekly Mail, 6 April 1993.

${ }^{95}$ Sachs, 'Lean and Clean'. More broadly: Spitz and Chaskalson, The Politics of Transition, pp.301-12.

${ }_{96}$ Moseneke, My Own Liberator, KL 4751-4752.

${ }^{97}$ Dubow, Human Rights, p.112.
} 
chief negotiator, Cyril Ramaphosa. ${ }^{98}$ The ANC accepted this compromise, but others saw it differently. Dikgang Moseneke described the property clause 'as perhaps the biggest give the liberation movement had to tolerate to get over the democratic winning line'. ${ }^{99}$

Moreover, South Africa's liberal legal establishment used the judicial nomination hearings to the new constitutional court to continue Cold War battles, subjecting Albie Sachs to an acerbic line of questioning about his alleged role in covering-up torture carried out by ANC counter-intelligence, MbokodoMkobodo. ${ }^{100}$ Etienne Murinek, a human rights scholar who had advised the Democratic Party during the constitutional negotiations, and later committed suicide during a bitter row about 'transformation' at the University of Witwatersrand, led the charge. ${ }^{101}$ Sachs later complained that the interview panel had shown no interest in his immersion in the radical legal debates that had been important to post-colonial states such as Mozambique, Tanzania and Zimbabwe:this experience 'didn't seem to count for anything. It didn't fit in with that notion of, you know, the only legal mind that counts is one attuned to the latest jurisprudential debates in Oxford, Columbia, Berlin and Leiden'. ${ }^{102}$

Given the deep tensions embedded in the process of negotiating the constitution and filling the first post-apartheid bench of the constitutional court, Nelson Mandela played a cautious

98 D. Smuts, 'Etienne Mureinik's Contribution to Property Rights', South African Journal on Human Rights, 14 (1998), pp.197-200.

${ }_{99}$ Moseneke, My Own Liberator, KL 4745-4746. More broadly: Spitz and Chaskalson, The Politics of Transition, pp.313-29.

100 This was a long-standing animus: South African jurists had blocked Sachs from attending a meeting they held with ANC exiles at a 1989 Oxford conference - LRCOHP interview, Albie Sachs, pp.52-3. Also: Bizos, Odyssey to Freedom, p.471.

${ }^{101} \mathrm{P}$. Trewhela linked these issues in his obituary of Etienne Murinek - Independent 23 July 1996. Also: M. Gevisser, 'June Sinclair: Velvet Fist in a Glove of Iron', Mail and Guardian, 4 October 1996.

${ }^{102}$ CCOHP interview, Sachs, p.6. Moreover, a well organised lobby of Wits law students protested against Yvonne Mokgoro, Kate O'Regan and Albie Sachs during the judicial service commission interviews, instead supporting the candidacy of their law school dean, June Sinclair - CCOHP interview, Bizos, p.9-10. 
hand when shaping the post-apartheid judiciary, using his choice of the chief justice to show his commitment to non-racialism. Here he chose Arthur Chaskalson to lead the new constitutional court - this time above the mercurial, equally brilliant, mercurial Ismail Mahomed - not only because Chaskalson was a sound administrator, but because Chaskalson was the establishment candidate. Mahomed, who was ill at the time, never fully recovered from the slight. 'He [Mandela] did not want a divided judiciary in the country.... [and] he knew that that Arthur [Chaskalson] was respected by the judiciary... [and] the legal profession, as a person of the highest integrity and ability', explained Bizos, who was close to the decision. ${ }^{103}$ Others saw things differently. Dennis Davis later told interviewers that whilst 'I think on an organisational basis... [Mandela] made the right decision, I have to say that there's something deeply ironic about a country that had an opportunity to appoint a black person as the first President of the Court and didn't do so.' ${ }^{\text {'104 }}$

Despite the controversy of surrounding Chaskalson's appointment, and objections by some black lawyers to the wording of the property clauses, Mandela's achievement was to find sufficient common ground around a discourse of positive rights. Yet this consensus was fragile: hence the debates about the transformation of the constitution and the judiciary that are seen today.

\section{Conclusions}

The story of how the ANC embraced constitutionalism is often told as one of how an organisation rhetorically committed to revolution and 'popular justice' as late as the mid1980 s, made an abrupt about-turn and adopted human rights just in time to enter the constitutional negotiations that would deliver a democratic South Africa in 1994. This

\footnotetext{
${ }^{103}$ CCOHP interview, Bizos, pp.10-11.

${ }^{104}$ CCOHP interview, Davis p.18.
} 
article has pointed in a different direction, showing how the ANC managed to rally a broad swathe of anti-apartheid lawyers behind their bill of rights proposals that promised 'positive freedoms' and a 'transformative constitution'. My suggestion here is that this second story deserves more attention. For it was by building a wide alliance of anti-apartheid lawyers broadly in favour of human rights and 'positive freedoms' that the ANC was able to win the battle of ideas in the constitutional negotiations.

This article has also emphasised the important role that Nelson Mandela played in welding together the rival groupings of human rights lawyers into a broad anti-apartheid coalition. Much of this was rooted in his personal biography. Mandela's experience of being an African lawyer in the segregated milieu of 1940s-50s Johannesburg was a narrative that resonated with a younger generation of black lawyers, not least those involved in the Black Lawyers Association from the mid-1970s onwards. Mandela also actively cultivated close connections to the influential coterie of Johannesburg-based liberal lawyers, who had first defended him at the 1963/4 Rivonia trial and later played a vital role in bringing the cause of South African human rights to the world in the 1980s. (He was not so close to the radical exile lawyers which is perhaps why he was willing to marginalise mavericks such as Albie Sachs.) It is also important to emphasise the politicking carried out by Nelson Mandela - and his loyal spear carriers, especially Geroge Bizos, Dullah Omar and Pius Langa - during the crucial years of the political transition. The Pan African Congress activist, Dikgang Moseneke, for instance, dedicates a whole chapter in his memoirs to the phone call by which Mandela charmed and persuaded him to join the institutional machinery that organised the first democratic elections. ${ }^{105}$ Other lawyers from across the political spectrum would also later recall the

\footnotetext{
${ }^{105}$ Moseneke, My Own Liberator, KL4763-4795.
} 
brilliant personal diplomacy by which Mandela co-opted them into the constitutional negotiations. ${ }^{106}$

At the same time, this article has highlighted the enduring disagreements about the meaning of human rights and transformative constitutionalism. Mandela made tough choices; above all, giving Arthur Chaskalson's Legal Resources Centre grouping the main role in the constitutional negotiations. By contrast, Presidents Mbeki and Zuma would more actively promote the cause of 'transformation' of the bureaucracy and judiciary - sometimes seemingly actively sidelining Chaskalson's younger protégés.

Indeed, an most important battleground in post-apartheid South Africa has been the 'transformation' of the judiciary. Advocates demanding affirmative action cite legal scholarship - in particular the fraught engagement in the US with questions of race and justice - in their pursuit the transformation of the courts. ${ }^{107}$ Critics counter that this stateengineered transformation threatens the independence of the judiciary and is an attack on the rule of law. ${ }^{108}$ More recently, a second battle front has opened as radical land activists have argued, once more, that the post-apartheid constitution was a hopeless compromise that entrenched unequal property tights. Thus 'Mandela's constitution' has become a lightningrod for bitter debates about race and inequality, more broadly, the meaning of human rights and transformative constitutionalism.

\footnotetext{
${ }^{106}$ CCOHP interviews, Bizos p.5, Davis p.12, Zak Yacoob 7 December 2011, p.9. ${ }^{107}$ CCOHP interview, Sachs, p.18-20. D. Ntsebeza, 'The Transformation of the Judiciary' (Fifth Annual Griffiths and Victoria Mxenge Memorial Lecture, 2014), available from http://law.mandela.ac.za/law/media/Store/documents/mxenge\%202014/Mxenge-LectureAdv-Ntsebeza.pdf, accessed on 18 June 2018.

${ }^{108}$ P. de Vos, 'What do we mean when we talk about Transformation?' 27 July 2009, available from http://constitutionallyspeaking.co.za/what-do-we-talk-about-when-we-talkabout-transformation, accessed on 18 June 2018. R.W. Johnson, South Africa's Brave New World: The Beloved Country since the End of Apartheid (London, 2010), p.147. More broadly: T. Halliday, L. Karpik, M. Feeley (eds), Fates of Political Liberalism in the British Post-Colony: The Politics of the Legal Complex (Cambridge, 2012).
} 


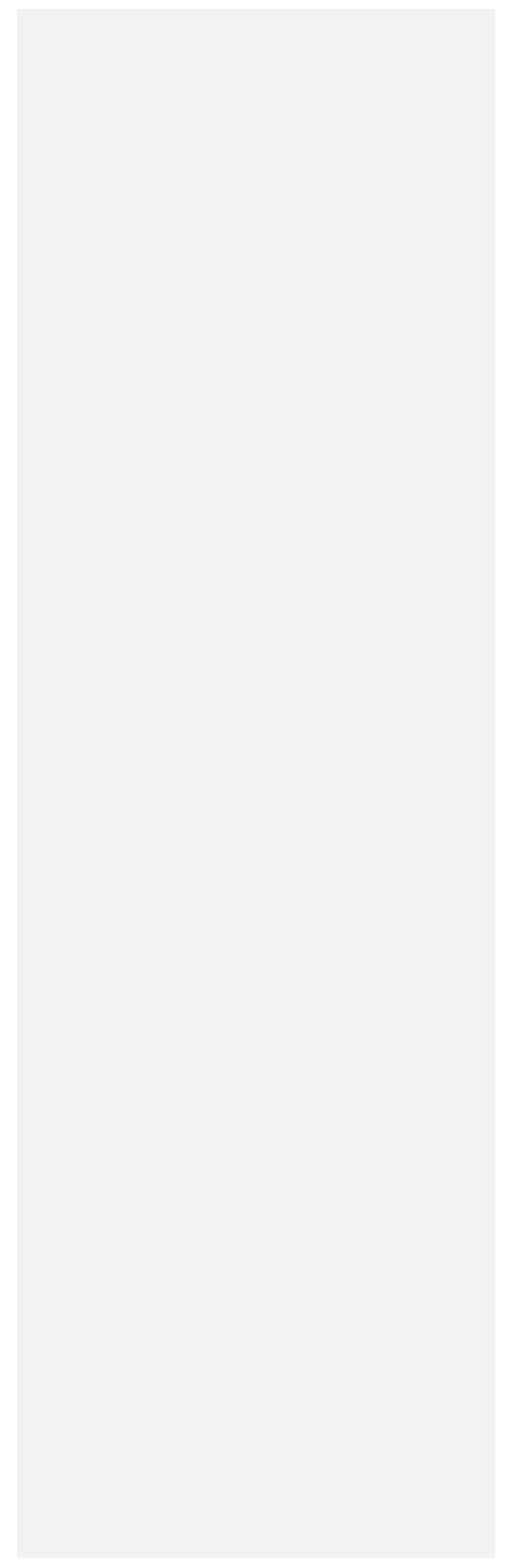

